\title{
Transformation of the Ethics of Public Authority in the context of changing paradigms of public administration
}

\author{
Yuri Denisov,", and Natalia Nemtsova \\ Siberian Law University, Department of Administrative and Financial Law, Korolenko Str., 12, \\ 644010 Omsk, Russia
}

\begin{abstract}
The research is devoted to the identification and analysis of the vectors of the evolution of the modern system of ethics of public authority. The first of them arose within the framework of the Weber paradigm, which consists in the codification of the norms of ethics of public authorities, which is largely anti-corruption. The second vector is associated with the introduction of the New Public Management paradigm and consists in reorienting the ethics of public authority and the personality of a civil servant to the service-management concept of public administration. The third vector emerged in line with the "Good Governance" paradigm. It focuses the ethical system of public authority on cooperation with all participants of the socio-political field and inclusiveness. In the context of the digitalization of the socio-political space, the Good Governance paradigm has begun a rapid evolution into the Digital Era Governance paradigm. Under these conditions, the public authorities faced an urgent need to modernize their ethical system, the need for its dynamic adaptation to rapidly changing technological realities and faced the challenges of a new ethics.
\end{abstract}

\section{Introduction}

Various aspects of the phenomenon of public authority today are at the intersection of the research interests of representatives of various fields of scientific knowledge about man, society, and the state. Public authority is inevitably the focus of attention of political scientists, specialists in the field of constitutional and administrative law, economists, philosophers, sociologists, and so on. A whole complex of factors contributes to the actualization of studies of different facets of this phenomenon. Among them, it is possible to distinguish changes in the mechanisms of functioning of state structures in the conditions of "covid" realities; challenges and opportunities for public administration systems generated by the steady digitalization of society; a new round of political and legal transformations in Russia, coupled with the constitutional consolidation of a unified system of public authority; increased protest activity almost all over the world, requiring the search

\footnotetext{
* Corresponding author: yurden1984@yandex.ru
} 
for new forms of communication between the authorities and various segments of society; permanently ongoing corruption scandals.

Among the most pressing problems of the functioning of public authority today are ethical problems. This is evidenced by the world-famous political scandals that have a pronounced ethical background. Among them, we can recall the attempts to impeach Donald Trump, and the discussion of the position of Joseph Biden regarding the investigations of the financial activities of his son Hunter Biden, and the corruption case of former French President Nicolas Sarkozy, and the information exaggerated in the media about the financing of expensive repairs to the apartment in Downing Street, where British Prime Minister Boris Johnson lives with his girlfriend, and rumors spread by the Russian non-systemic opposition about the "palace of Vladimir Putin". Against the background of such a media agenda, the concept of a new ethics, set out by Erich Neumann in his book "Deep Psychology and the New Ethics" [1], is becoming increasingly loud. At the same time, scientific rethinking of the ethics of public authority is also required by the steadily increasing possibilities of computerization and automation of a wide range of processes, virtualization of communication practices and the introduction of blockchain technologies, which can transform the very mechanism of state and municipal management and require the development of new ethical standards of interaction between its subject and object, and tectonic technological developments that have already occurred at the turn of the millennium, socio-economic and political shifts have actually changed the very paradigm of public administration and socio-political development several times.

In this regard, the purpose of this study was to analyze the vectors of development of mechanisms of ethical regulation of relations in the field of public administration, which manifested themselves in the second half of the twentieth century - the first two decades of the XXI century.

\section{Materials and Methods}

This study is based on a systematic approach that allows us to consider the phenomenon of public authority ethics as a whole complex, a set of interrelated and interacting elements. During the research, we collected, analyzed, synthesized, and processed information. As materials, we used normative and non-normative legal documents, sources of mass media and scientific works on the issues of interest to us. At the same time, the study of the phenomenon of ethics of public authority is retrospective and involves its consideration in the development mainly over the historical period covering the second half of the last century and the first two decades of the twenty-first century.

\section{Results and Discussion}

The problems of ethical regulation of the system of public authority and public service have deep historical roots, going back to the moral models and political practices of the Ancient World. As the Irish researcher of the axiological aspects of the public service phenomenon, M. MacCarthaigh, notes, "concern with values, standards and ethics in public life is not new» [2]. A kind of ethical basis for public authority was laid in ancient Rome. The ethics of public $\mathrm{p}$ authority in close conjunction with political ethics were considered by the ancient Greek philosophers Plato and Aristotle, who saw a clear correlation between the ethics of authority and the ethics of society. In fact, the ethical system of public authority, built by medieval religious scholasticism, was proposed by Thomas Aquinas and Augustine the Blessed. In Modern times, N. Machiavelli proposed his own interpretation of the ethics of public authority, pointing out the autonomy of politics from morality. And M. Weber 
divided political ethics into two types: "the ethics of the ideal" and "the ethics of responsibility".

However, the development of ethical regulation of relations in the sphere of public authority received a special impetus in the second half of the last century, when the first attempts were made to officially codify the ethical norms of the public service. In particular, in the United States, "Code of ethics for government service" appeared on July 11, 1958 in the form of Congressional Resolution No. 175. The document contains ten principles that every person in the government service should follow. The first of these is: "Put loyalty to the highest moral principles and to country above loyalty to persons, party, or Government department". The anti-corruption vector was clearly articulated in this code. Its ninth these states: "Expose corruption wherever it is found" [3].

Over time, the trend of codifying the ethics of the public service and its close integration with the anti-corruption policy has found its expression at the international level. A kind of turning point in the dynamics of this vector of development of mechanisms for the ethical regulation of public authority was December 12, 1996, when the "International Code of Conduct for Public Officials" appeared at the 82nd plenary session of the UN General Assembly. It was adopted by Resolution 51/59 and received a pronounced anti-corruption orientation. The sections were devoted to conflict of interest and its resolution, the mechanism for officials to report information about their assets, the problem of accepting gifts and other tokens of attention, confidential information and political activities of public officials [4]. Thus, the main line in the regulation of ethical relations at the international level has become the fight against corruption and its prevention.

In Russian political and legal practice, this line found its vivid expression in 2010, when the decision of the Presidium of the Council under the President of the Russian Federation on Combating Corruption approved the Model Code of Ethics and Official Conduct of Civil Servants of the Russian Federation and Municipal Employees. Without being a normative legal act, it largely absorbed the norms that at that time were already enshrined in the Russian anti-corruption legislation, the laws on state and municipal service, especially in terms of prohibitions and restrictions, as well as in the Decree of the President of the Russian Federation "On the approval of the General Principles of Official Conduct of Civil Servants". This model Code somehow formed the basis of the codes of ethics of all State civil servants and municipal employees. Similarly, the ethical standards of other types of public service were codified. Attention was also paid to the ethical regulation of military service. The Federal Law "On the Federal Security Service" introduced a norm that obliges employees of the federal security service to comply with the code of ethics and official conduct approved by the head of the federal executive authority in the field of security. It also affected the ethical regulation of persons holding public positions. On December 19, 2012, the VIII All-Russian Congress of Judges approved the Code of Judicial Ethics.

The codification of ethical norms generally followed the Weberian paradigm of state and municipal administration, with its clear formalization of the competence of state and municipal employees, the vertical hierarchy of the bureaucracy, and the regulation of behavior through clearly defined universal prescriptions. It largely unified the ethics of the public authorities, clearly defined its formal framework and closely linked the mechanism of ethical regulation of public administration with the mechanism of regulatory legal regulation, focusing on the implementation of anti-corruption policies and ensuring the implementation of official prohibitions and restrictions.

At the same time, as a result of administrative reforms that unfolded in the 80-90s of the last century, in Great Britain, New Zealand, Australia, the USA, and Canada, the Weberian paradigm of state and municipal management is gradually giving way to the New Public Management paradigm. This paradigm also transforms the ethics of public authority. 
Within its framework, public managers were tasked with either finding new effective and innovative ways to achieve results, or delegating functions previously performed by the state to private hands. As Janet and Robert Denhardt write, state managers have been urged to "steer, not row." This means that «they should not assume the burden of service delivery themselves, but, wherever possible, should define programs that others would then carry out, through contracting or other such arrangements. The key is that the New Public Management relies heavily on market mechanisms to guide public programs» [5]. In the Russian Federation, the introduction of the managerial paradigm into the practice of state and municipal management was actively implemented during the administrative reform of 2005-2010. It was characterized by the emergence of multifunctional centers for the provision of state and municipal services, the delegation of functions of state authorities to state corporations, state-owned companies and companies with state participation, the intensive use of political discourse by persons holding public positions, terminology characteristic of professional managers, the spread of the practice of evaluating state and municipal employees and employees of budget organizations from the point of view of efficiency, etc.

Under these conditions, the public service has increasingly become focused on providing services to the population in a market economy. The managerial approach to public administration and the service model of relations between public authorities and society have become widespread. With the introduction of the NPM concept in the public service system, the bureaucratic model of control and accountability with its principles of hierarchy and separation of internal and external functions has ceased to be considered as axiomatic [6]. The work of the public servant and the public service is based on seven principles: "serve, rather than steer"; "the public interest is the aim, not the by-product"; "think strategically, act democratically"; "serve citizens, not customers"; "accountability isn't simple "; "value people, not just productivity"; "value citizenship and public service above entrepreneurship" [7].

As a result of the implementation of the concept of "New Public Management", as stated by the Dutch researcher J. van Bockel, a "flexible public service identity" emerged. It is based on the" entrepreneurial spirit " of the public servant, applied for the benefit of society and the state. In the foreground is the effectiveness of the public service and its clearly measurable indicators, depending on which the financial incentives of the public servant vary [8].

However, the transformation of the public service paradigm did not end with the establishment of the New Public Management, nor did the changes in the ethical system of the public authority end there. Understanding the world experience highlighted the shortcomings of the managerial paradigm of public administration, including: the secondary nature of solving social problems, the erosion of the role of the state and civil servants in public relations, and insufficient consideration of the specifics of the institutional context [9]. The answer to the challenges posed by these problems was the spread of the "Good Governance" paradigm of public administration. It focused on partnerships in which politicians and civil servants make decisions together with other sectors of society, focusing on the individual and integrating the autonomous capabilities of citizens in the process of solving social problems.

De facto, this meant replacing the service-management paradigm of public management with the participatory paradigm. It involves focusing on the cooperation of state authorities with local self-government, civil society institutions, commercial organizations and the population, and ensuring the participation of various actors in a single system of public administration [10]. This requires at the same time a reorientation of the ethics of public authority towards the values of cooperation and participation. The demand for them is also reinforced by the ongoing intensive digitalization of management practices, a powerful 
catalyst for which was the coronavirus pandemic. It inevitably removes barriers and distances between public authorities, civil society institutions and individuals, and opens up new opportunities for political participation. New technological opportunities also create new communication problems, at the same time open up opportunities for the manifestation of new forms of censorship and create limitless conditions for the dissemination of uncontrolled information flows.

The shift of the entire spectrum of communication practices to the polydiscursive space of the Global Network largely contributes to the emergence of the total effect, which A. I. Solovyov describes as "the gradual removal of the centers of state decision-making beyond the framework of administrative hierarchies" [11]. The reaction to the technological revolution is the emergence of the Digital Era Governance (DEG) paradigm, which also requires the transformation of the ethical system of public authority. This paradigm is based on the integration of the tasks facing the state in Big Data, which simultaneously contribute to the centralization and networking of management processes, the intensive use of web technologies and social networks in the activities of public servants, and the orientation of public authorities to systematically meet the needs of citizens through modern technologies. [12]. At the same time, some researchers at this stage fix the signs of the third wave of the DEG paradigm, associated with the formation of a network structure in management systems and reflecting the renewal of the concept of digital government itself, its rebirth into the concept of a network-based digital government, that is, a government that actively uses new management systems based on cyber-physical (digital) systems with a basic network multi-agent component [13].

From the perspective of the digitalization of public authority, the concept of a new ethics also takes on specific forms. The globalized, multicultural, polydiscursive, and extremely diverse cyberspace also forces the public authorities to implement, to one degree or another, many of the foundations of the new ethics linked by a social, feminist, antisexist, anti-racist, and anti-nationalist agenda. At the same time, the spread of a new ethics generates a new censorship, based on the phenomenon of "cancel culture". The new ethical censorship often turns out to be politicized. And the actors that implement the new ethical censorship are often non-state or supranational actors, such as multinational corporations, Internet platforms, or large network communities that actually take over the functions of public administration.

However, paradoxically, the process of networking of public authority, which can significantly reduce the power of individual large platforms within the new wave, does not mean the destruction of the established codified system of ethics of public authority. Opening up almost limitless communication opportunities for the public authorities, it only points to the need to develop their ethics in a participatory and innovative vector and supplement the ethical system with norms that take into account the specifics of the increasingly automated and virtualized mechanism of public administration.

\section{Conclusions}

Thus, the ethics of public authority as a system in the second half of the twentieth and the first decades of the twenty - first centuries underwent a significant transformation, which was inextricably linked with the transformation of the very paradigm of public administration. In the process of this transformation, several vectors can be distinguished. The essence of the first of the vectors identified by us is the codification of the norms of ethics of public authorities and their normative and legal consolidation. It was born in the $50 \mathrm{~s}$ of the last century within the framework of the Weberian paradigm and developed in close conjunction with the implementation of anti-corruption policy. The origins of the 
second vector originate in the administrative reforms that unfolded in the Anglo-Saxon countries in the $80 \mathrm{~s}-90 \mathrm{~s}$ of the last century, which were marked by the introduction of the New Public Management paradigm, which gradually replaced the classical Weberian paradigm. It consists in reorienting the ethics of public authority and the identity of the civil servant to the service-management concept of public administration. The key benchmarks of this ethical model are market efficiency, the satisfaction of the population with the provision of state and municipal services, the delegation of the functions of state authority to non-state actors, the following of civil servants who provide services to citizens for the "top managers" of public power who rule the system. The emergence of the next vector is due to the understanding of the shortcomings of the New Public Management paradigm and its transformation into the "Good Governance" paradigm. The structure of the basic elements of the ethics of public authority includes a focus on cooperation with all participants in the socio-political field and inclusiveness. Under the influence of powerful and dynamic technological shifts that change the entire set of socio-economic and sociopolitical practices, the Good Governance paradigm is closely intertwined with the Digital Era Governance paradigm. In the context of multi-agency public administration and the emergence of new technological forms of political participation, the ethical system of public authority is under the intense influence of the concept of a new ethics and faces serious challenges. The networkingization of public authority $r$ and the increasing automation and virtualization of public administration require the modernization of the ethics of public authority, which today is a multi-layered system formed in the process of changing a number of paradigms of public administration.

\section{References}

1. E. Neumann, Deep Psychology and the New Ethics (1990)

2. M. MacCarthaigh, Public Service Values, 5 (2008)

3. Code of ethics for government service (1958)

4. International Code of Conduct for Public Officials A/RES/51/59 - E - A/RES/51/59 Desktop (undocs.org)

5. J. Denhardt, R. Denhardt, The New Public Service: Serving, not Steering, 13 (2007)

6. G. L. Kupryashin, Publichnoe upravlenie, Politicheskaya nauka, 2, 108 (2016)

7. R. Denhardt, J. Denhardt, Public Administration Review, 6(60), 553 (2000)

8. J. van Bockel, Identities of Public Servants, Performance-driven, but Professional Public Managers, 9 (2005)

9. D. G. Krasil'nikov, O. V. Sivinceva, E. A. Troickaya, Ars Administrandi, Iskusstvo upravleniya, 2, 47 (2014)

10. L. M. Smorgunov, Vlast', 11, 27 (2017)

11. A. I. Solov'ev, Polis, 4, 12 (2019)

12. H. Margetts, P. Dunleavy, Philosophical Transactions of the Royal Society, 371, $1(2013)$

13. G. L. Kupryashin, A.E. Shramm, Gosudarstvennoe upravlenie, Elektronnyj vestnik, 84, 269 (2021) 